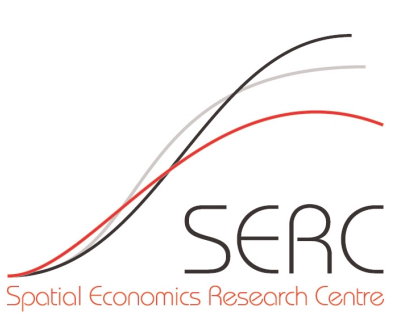

\title{
Does Decentralization Matter for Regional Disparities? \\ A Cross-Country Analysis
}

Andres Rodríguez-Pose (SERC, London School of Economics)

Roberto Ezcurra (Departamento de Economia, Universidad Publica de Navarra)

July 2009 
This work was part of the research programme of the independent UK Spatial Economics Research Centre funded by the Economic and Social Research Council (ESRC), Department for Business, Enterprise and Regulatory Reform (BERR), the Department for Communities and Local Government (CLG), and the Welsh Assembly Government. The support of the funders is acknowledged. The views expressed are those of the authors and do not represent the views of the funders.

(C) A. Rodríguez-Pose and R. Ezcurra, submitted 2009 


\title{
Does Decentralization Matter for Regional Disparities?
}

\author{
Andrés Rodríguez-Pose* and Roberto Ezcurra**
}

July 2009

* SERC, Department of Geography and Environment, London School of Economics ** Departamento de Economia, Universidad Pública de Navarra

Acknowledgements

The authors are grateful to Ramiro Gil Serrate for his work in the compilation and setting up of the database. The research has been financed by the Centro Internacional de Estudios Economicos y Sociales (CIEES). It is also part of the research programme of the independent UK Spatial Economics Research Centre funded by the Economic and Social Research Council (ESRC), Department for Business, Enterprise and Regulatory Reform, Communities and Local Government, and the Welsh Assembly Government. The support of these funders is acknowledged. The views expressed are those of the authors and do not necessarily represent the views of the funders. 


\begin{abstract}
$\underline{\text { Abstract }}$
This paper looks at the relationship between fiscal and political decentralization and the evolution of regional inequalities in a panel of 26 countries - 19 developed and 7 developing - for the period between 1990 and 2006. Using an instrumental variables method, it finds that whereas for the whole sample decentralization is completely dissociated for the evolution of regional disparities, the results are highly contingent on the level of development, the existing level of territorial inequalities, and the fiscal redistributive capacity of the countries in the sample. Decentralization in high income countries has, if anything, been associated with a reduction of regional inequality. In low and medium income countries, fiscal decentralization has been associated with a significant rise in regional disparities, which the positive effects of political decentralization have been unable to compensate. Policy preferences by subnational governments for expenditure in economic affairs, education, and social protection have contributed to this trend.
\end{abstract}

JEL Classifications: H11, H71, R11

Keywords: Fiscal decentralization, political decentralization, regional disparities, territorial inequality, fiscal redistribution 


\section{Introduction}

Over the last forty years a decentralizing wave has swept the world. Whereas in the early 1970 s the number of truly decentralized countries - not including those that were only decentralized on paper - was rather limited, decentralization is now an essential feature of political regimes the world over. It has been at the centre of policy transformations not only in developed countries, but also in many developing and transition economies in Asia, Latin America, and Africa (Bardhan, 2002: 185). The decentralization process is still in full swing (Marks, Hooghe and Schakel, 2008), with subnational movements, national governments, and international organisations alike often acclaiming the virtues and benefits of decentralized governments (e.g. Burki, Perry and Dillinger, 1999; World Bank, 2000).

The political rationale for decentralization has also evolved, shifting from an emphasis on cultural, ethnic, linguistic, or religious factors, to one of achieving economic and social change. Decentralization has been increasingly sold by powerful central elites, as well as by a growing raft of nationalist and regionalist groups, as a way to attain greater efficiency and competitiveness and to accomplish a better insertion into a globalised world (Rodríguez-Pose and Sandall, 2008: 66). The view of decentralization has thus shifted from that of an instrument to avoid homogenisation and economic change to that of a vehicle to achieve it (Rodríguez-Pose and Gill, 2005: 407-8).

Yet, so far, the overall implications of decentralization for economic development are poorly understood. There is an important gap in the literature, as the studies that have tried to venture into the economic implications of decentralization 1) are few and far 
between; 2) often focus on individual case studies; and 3) generally reach contradictory conclusions. Many questions thus remain unanswered. Is it true that decentralization generates what Morgan (2002) calls an 'economic dividend'? Does it lead to greater economic efficiency and growth? Is it associated to a lowering or rising of economic disparities? In particular, this last question - despite some notable exceptions that have mainly focused on the impact of decentralization on regional inequalities in specific countries - has either been fundamentally overlooked by the literature or too easily dismissed on the basis that decentralized political structures not only lead to smaller governments, but also to "a less-developed welfare state, and, consequently, higher levels of inequality" (Beramendi, 2007: 783).

This paper addresses the question of what have been the implications of the recent trend towards decentralization for the evolution of territorial inequalities across twenty-six developed and transition and/or developing countries across the world. More precisely, it aims to improve our understanding about whether the global transfer of authority and resources to subnational tiers of government may yield different results in terms of territorial equity in the developed and the less developed worlds and across countries which have diverse histories and levels of decentralization and which have adopted different paths towards it.

The key hypothesis driving the paper is that while, on the whole, the positive and negative effects of fiscal and political decentralization may offset one another, capacity and financial resource constraints and weaker endowments in the poorer regions of lower income countries may exacerbate the negative impact of decentralization on territorial inequality. Less developed countries with already existing high territorial 
imbalances will, as a consequence, tend to exhibit growing inequalities once they decentralize, while the effect of decentralization in the developed world may be either neutral or even contribute to a reduction of regional disparities.

In order to address whether this is the case, the paper first looks at the spatial implications of decentralization, focusing initially on how the process of decentralization has acquired global dimensions, before concentration on the theoretical links between decentralization and territorial inequalities. Section 3 presents the model and the data and comments on the empirical results of regressing fiscal and political decentralization on the evolution of regional inequalities. It also looks how different choices in types of expenditure by subnational governments may have affected regional economic trajectories and disparities. The final section concludes.

\section{The spatial implications of decentralization}

\subsection{Decentralization as a global trend}

In contrast to the situation in the early 1970s, when most countries were centralized nation-states, today "some 95 percent of democracies [...] have elected subnational governments, and countries everywhere - large and small, rich and poor - are devolving political, fiscal, and administrative powers to subnational tiers of government" (World Bank, 2000: 107). The trend towards decentralization has been relentless and widespread among most large countries in the world, regardless of their level of development ${ }^{1}$.

${ }^{1}$ In an analysis of regional authority trends in 42 countries between 1950 and 2006, Marks, Hooghe and Schakel find that the process of decentralization has been "one- 
Within the developed world, there is virtually no large country that has not witnessed some degree of decentralization over the last four decades. In Europe - on top of the already federalized Austria, Germany, and Switzerland - Belgium, Italy, and Spain have introduced widespread reforms in order to enhance regional autonomy. France and Poland have taken more limited steps towards regionalisation, with the creation of regions and directly elected assemblies. And the UK and Portugal - together with Spain and Italy - have opted for asymmetrical forms of devolution and transferred a considerable amount of powers to some of their regions (Hooghe, Schakel and Marks, 2008). Many countries in central Europe engaged in significant decentralization on or before their accession to the EU, with some already embarking on a 'second generation' of reforms since transition (Hooghe, Schakel and Marks, 2008). A number of transition countries throughout eastern Europe and central Asia have also decentralized (DablaNorris, 2006: 104).

Moves towards even greater decentralization have also been common among nationstates which enjoyed significant subnational autonomy before the onset of globalization. In the US, for example, the trend towards centralization, which some trace back to the American Civil War or to the Great Depression, was turned on its head by Reagan's New Federalism in the 1980s, when states began to recover greater freedom of action (Donahue, 1997). The powers of US states have continued to grow under both Democratic and Republican administrations in the 1990s and 2000s. Australia and

sided over quite an extended period of time" (Marks, Hooghe and Schakel, 2008: 170). Only two of the 42 countries considered witnessed some level of recentralization, while 29 saw an increase in regional autonomy. In addition, $89 \%$ of the 384 reforms examined resulted in an expansion of regional authority. 
Canada have equally experienced modest increases to their already significant levels of decentralization (Hooghe, Schakel and Marks, 2008).

The true global nature of the phenomenon is in evidence when the trends towards subnational autonomy in the developing world are taken into consideration. Among the low and middle income countries in Asia, China, Indonesia, the Philippines, and Vietnam, among others, have undertaken significant leaps towards regional autonomy. These changes have ranged from radical reforms of the state, as in the case of the 1999 decentralization of Indonesia (Aspinall and Berger, 2001), to gradual de facto transformations of the relationship between the centre and the regions, as has been the case in China, where regional and local governments enjoy high levels of economic and fiscal autonomy (Ma, 1996: 5). India, a federal state since independence, has undergone a new wave of decentralization since 1992 (Sharma, 1999; Bagchi, 2003).

In Latin America, many of the countries that were decentralized on paper have also undergone profound transformations. This is, for example, the case of Mexico, which witnessed a renewal of federalism in the 1990s (Rodríguez, 1998; Ward and Rodríguez, 1999), or of Brazil, where the 1988 constitution afforded states a hitherto unprecedented level of autonomy (Coutinho, 1996; Dillinger and Webb). Even sub-Saharan Africa, long regarded as a strong bastion of centralism, has undergone significant transformations in its territorial organisation. Extensive transfers of powers to subnational tiers of government have taken place in South Africa, Uganda, and Nigeria, while most other countries within sub-Saharan Africa have experimented with different levels of regional autonomy, with moderate to far-reaching transfers of powers and 
resources to subnational tiers of government occurring in at least thirteen of them (Ndegwa, 2002).

\subsection{Decentralization and territorial inequalities}

The recent global drive towards decentralization has been, to a large extent, based on a different rationale than previous decentralization trends (Rodríguez-Pose and Sandall, 2008). While traditionally the transfer of powers and resources to subnational tiers of government was justified on identity grounds - i.e. the need to preserve a distinct cultural, linguistic, historical, or religious traditions within large and heterogeneous states (Hechter, 1975; Horowitz, 1985; de Winter and Türsan, 1998; Moreno, 2001) the recent wave of decentralization has, according to the 'new regionalist' literature in political science, tended to be justified on the grounds of a supposed greater capacity of subnational governments to overcome the failures of the centralized state (Bardhan, 2002: 185) and to deliver improved economic efficiency (Keating, 1998; Morgan, 2002).

The supposed superior economic efficiency of decentralized governments rests on the basic tenets of the fiscal federalism literature. Tiebout (1956) and Oates (1972) posit that the transfer of authority and resources to subnational tiers of government leads to a double improvement in efficiency. The first and perhaps most important economic advantage associated with decentralized governments is their capacity to match public spending better to the heterogeneous preferences of individuals living in different territories, thus enhancing the allocative efficiency of government. The second advantage of decentralization lies in its capacity to mobilize underused resources and in the competition it creates among subnational governments in order to deliver better 
policies. Mobilizing resources to their full potential and greater competition among jurisdictions may result in a more efficient provision of public goods and services and in greater policy innovation, thus increasing the overall productive efficiency of an economy (Oates, 1996).

Yet, the enthusiasm for the positive economic implications of political decentralization is often tempered by the belief that the distribution of its benefits is geographically uneven and that "unfettered fiscal decentralization is likely to lead to a concentration of resources in a few geographical locations and thus increase fiscal disparities across subnational governments" (Martínez-Vázquez and McNab 2003: 1605). Despite some claims that decentralization is associated with a general reduction in territorial disparities (e.g. Weingast, 1995; McKinnon, 1997; Qian and Weingast, 1997; Shankar and Shah, 2003, Gil, Pascual and Rapún, 2004), the prevailing view is that the transfer of powers and resources to subnational tiers of government disproportionally benefits those regions with a greater capacity to really fulfil allocative and productive efficiency, i.e. the most prosperous regions, with better socio-economic endowments and better institutions (Cheshire and Gordon, 1996). In addition, as decentralization undermines the power of the central state to play an equalising role, it may lead to a transfer of economic development from the peripheries to the cores (Prud'homme, 1995; Rodríguez-Pose and Gill, 2004). Hence the widespread perception that decentralization and greater territorial inequalities are the two sides of the same coin and that "there is clearly a tension between pursuing goals of equality in service provision and greater decentralization and choice" (Besley and Ghatak, 2003: 245). 
The mechanisms through which decentralization may result in greater territorial disparities are, according to Rodríguez-Pose and Gill (2005), of an economic and political nature. From an economic perspective, the differences in institutional capacities and socio-economic endowments among regions within any given country may undermine the potential benefits associated with the better matching of policies to local needs and the greater territorial competition associated with decentralization. In the cases of regions with pockets of extreme poverty, where basic necessities need to be covered, decentralization may not mean a better matching of the provision of goods and services to the preferences of the population, but simply a different and perhaps a less efficient way - because of the loss of economies of scale - of delivering basic goods and services (Prud'homme, 1995). In most other cases, weaker and often times more corrupt institutions, lower access to capital, smaller tax bases, and weaker infrastructural, educational, and technological endowments represent a serious handicap for poorer regions within any given country in order to deliver greater allocative and productive efficiency through decentralization. This may also mean that the poorer a region or a subnational state, the weaker its capacity to compete for the attraction of capital, foreign direct investment, or talent. And less capital, investment, and talent automatically implies a lower capacity to innovate. Hence, under a more decentralized regime, it is often assumed that the playing field is not level and that the poorer and less well endowed regions face significant constraints that would prevent them from delivering and innovating in the same way as their richer counterparts, thereby perpetuating pre-existing patterns of disparities in the provision of goods and services and in wealth. 
From a more political perspective, decentralization may imply a reduction of the influence of poorer regions and states over the allocation of financial resources and transfers. Decentralization entails granting subnational governments a greater say over policy-making and over the collection and distribution of financial resources. The transfer of financial powers to subnational governments is likely to create inequities among richer and poorer regions both immediately after the transfer of powers and in the medium and long-term. In the short term, the transfer of the powers to tax downwards from the central state will yield greater rewards to territories with a more developed economic fabric and thus a greater tax base. In the medium and long-term a more dynamic and subtle mechanism of political influence may kick in and contribute to perpetuate and enhance existing territorial disparities. The process of decentralization will almost certainly unleash a competition for the scarce resources emanating from the central government, with subnational authorities bidding for an ever greater share of the national economic cake. Hence, the central government is likely to find itself at the heart of "conflicting demands of states that are competing for its patronage" (Rodríguez-Pose and Gill, 2005: 412). However, the playing field in this competition for resources is not level, with richer, stronger, and/or larger states likely to wield a greater influence over central decision-making than lagging, poor, or remote states. Such influence can be used in order to extract a more discretionary allocation of funds from the central government, to the detriment of formula-based solutions - which are more likely to be favourable to those territories with greater needs or endowment shortages - as has been the case in Mexico or to try to modify formula-based systems with the introduction of criteria and indicators more favourable to the richer regions, as in the recent negotiations to transfer financial autonomy to Spanish regions. This, in turn, will undermine the redistributive capability of the state and leave regions in the 
periphery more exposed and vulnerable under what can become a territorially regressive financial system, as was observed in Brazil (Dillinger and Webb, 1999) or in India (Rao and Singh, 2007) .

There are, however, circumstances where it can be envisaged that greater decentralization may contribute to reduce, rather than increase, territorial inequalities. First, the transfer of authority and resources to subnational governments is likely to generate greater transparency and bring to light differences in the provision of goods and services across jurisdictions, putting both subnational governments and the central government under pressure in order to a) deliver more efficient goods and services and b) equalise towards a maximum common denominator the provision of those goods and services within any given country. Decentralization in Canada, for example, which initially led to the establishment of a more progressive and egalitarian welfare state in Québec in comparison to other Provinces, may have later "contributed to strengthening social protection elsewhere in Canada" (Béland and Lecours, 2009: 22).

Decentralization is also about promoting efficiency everywhere. Local and regional governments mobilize local resources with the aim of delivering greater allocative and productive efficiency. The use of a territory's endogenous potential varies significantly from one place to another. If we assume that more advanced regions are closer to using their full economic potential or, in other words, to their economic frontier, then the margin of improvement will be greater in less developed areas. Under these circumstances, decentralization may be a catalyst for economic convergence. The transfer of authority and resources to subnational tiers of government also generates a series of incentives for competition that may also contribute to equalize regional 
standards of living and wealth. In democratic systems, subnational governments have strong incentives to deliver greater growth and to achieve levels of development similar to those of the most developed regions within any nation-state in order to be able to convince the electorate to vote for them to remain in power (Weingast, 1995; Qian and Weingast, 1997; Ezcurra and Pascual, 2008). This incentive is greater for less developed regions within any given national context, who may resort to greater fiscal competition or more flexible labour markets than their richer counterparts (McKinnon, 1997; Shankar and Shah, 2003). However, the objectives of equalizing the provision of public goods to the maximum common denominator with the need to compete on fiscal grounds and more flexible labour markets may be hard to reconcile in the absence of a very strong redistribution of funds by the central government and in the presence of strong regulatory systems.

One aspect that has been often overlooked is the fact that the factors that may push decentralized regimes towards greater or lower territorial inequality are likely to operate differently in diverse economic environments. Hence while many of the assumptions that link decentralization to greater territorial inequality may be valid for poorer countries with high existing territorial disparities and weak institutions, this may not be the case in richer, more equal, and more institutionally developed environments. Developed countries are not only wealthier than developing ones, they also have significantly lower territorial inequalities ${ }^{2}$. Therefore, while the capacity constraints that

\footnotetext{
2 In our sample, the lowest territorial disparities in 2004-2005 - measured by the population-weighted coefficient of variation - are found in the US. Most of the developed countries in the sample have levels of disparities that did not exceed two times those of the US in that year. In contrast, in the developing world, disparities were 3.2 times higher in Brazil, 3.4 times higher in India, 3.8 times higher in South Africa, 4.5 times higher in China and Mexico, and 8.6 times higher in Thailand than in the US.
} 
are at the base of the link between decentralization and growing regional inequalities are certainly an important issue in relatively poor and unequal countries across the developing world, they may not matter significantly in the developed world. The governments of the poorest regions in Brazil, Mexico, South Africa, or Thailand are much more likely to face serious institutional constraints than those of São Paulo, Mexico City, Gauteng, or Bangkok. First, because of the need to cover basic necessities in their constituencies, they may be forced to spend their scarce resources on delivering basic goods and services, rather than on tailoring policies to the specific preferences of their populations. Hence, the choice that is at the base of the fiscal federalism theories will not apply in the peripheral areas of the developing world. Second, these regions are more likely to suffer from institutional problems, such as weaker, more corrupt, and less transparent organisations (Martínez-Vázquez and McNab, 2003). Local and regional governments in these areas may be more prone to capture by local elites than government in richer regions or the national government. As Bardhan (2002: 194) indicates "in situations of high inequality, collusion may be easier to organize and enforce in small proximate groups involving officials, politicians, contractors and interest groups; risks of being caught and reported are easier to manage, and the multiplex interlocking social and economic relationships among local influential people may act as formidable barriers to entry into these cozy rental havens". And weaker and more corrupt institutions will, in turn, negatively affect the incentives to respond and promote efficient policies at the local level (Bonet, 2006: 662). Local governments are also likely to attract less qualified people than governments in core areas, as migration trends towards the core would have already creamed off some of the most able and better qualified individuals. They will also be less likely to compete on a level playing field as only territories with good institutions, accessibility and infrastructure, and an 
investor-friendly environment will succeed in generating and attracting private investment (Bagchi, 2003: 34). In addition, poorer and more agricultural regions will have to rely more on levies and compulsory apportionment in order to raise funds, further limiting their economic growth potential (Kanbur and Zhang 2005: 92). Finally, as a consequence of the presence of a weaker civil society and of lower public spending and less developed or even absent territorial redistribution and equitable territorial transfer systems, the influence that lagging regions may exert over the political process and the territorial distribution of funds may be limited or even waning (Bonet, 2006: 672).

These factors need not necessarily apply in the developed world. Although the gap in development between West Virginia or Mississippi, on the one hand, and Connecticut or California, on the other, may be considered as significant, it is not necessarily the case that state governments in West Virginia or Mississippi may not have the capacity to implement their own autonomous policies that reflect the preferences of their citizens and may not be able to attract suitably qualified personnel. Given the well-established territorial checks and balances of the US government system, these states may even have greater per capita political influence than some of their richer and most prosperous counterparts on how federal funds are distributed. And in none of these states would the state government be concerned in the same way as in the developing world with covering the basic necessities of the population. The same is valid in virtually all regions in the developed world. As a consequence, any negative association between decentralization and devolution of regional disparities will be much more prominent in the developing world than in developed countries. In the latter, because of the presence of strong redistribution regimes associated with high levels of government expenditure, 
the effect is likely to be neutral or even perhaps mildly positive (Ezcurra and Pascual 2008). Following Beramendi (2007: 786), it may not be the case that it is "decentralization that causes inequality, but rather pre-existing economic inequalities that drive the decentralization of the welfare state, which in turn reproduces the preexisting patterns of inequality".

The empirical evidence regarding the connection between decentralization and the evolution of regional disparities is, as mentioned in the introduction, scarce and inconclusive. Among the studies which have focused on individual country cases, most tend to find a positive relationship between decentralization and regional disparities. Bagchi (2003) for the case of India, Bonet (2006) for Colombia, Hill (2008) for Indonesia, Silva (2005) and Hill (2008) for the Philippines, Pike and Tomaney (2009) for the UK, Warner and Pratt (2005) for the US, and West and Wong (1995), Tsui (1993), Chen and Fleischer (1996), Dayal-Gulati and Husain (2002), Kanbur and Zhang (2005), Qiao, Martínez-Vázquez and Xu (2008) for China all find that moves towards decentralization have been accompanied by an increase of territorial disparities. The number of single country studies that find that decentralization is either unrelated or indeed associated with a decrease in regional inequalities is far more limited. These include Calamai (2009) for Italy and Lee (1995) or Wei and Wu (2001) for China. Studies using cross country data reach similarly incomplete conclusions. Among those dealing with the developed world, Gil, Pascual and Rapún (2004) and Ezcurra and Pascual (2008) find that decentralization has contributed to an increase regional convergence. Rodríguez-Pose and Gill (2004), in a study that covers both countries in the developed and developing worlds, find mixed evidence depending on the countries, but a prevailing tendency for the devolution of political and fiscal powers to be 
associated with increasing disparities. In the end, all these studies either cover a limited range of country cases - and fundamentally China - or, in the case of the cross-country studies, a small subset of fundamentally developed countries. They also reach far too contradictory results for any clear pattern to emerge. However, by and large and in accordance with our hypothesis, the majority of the studies focusing on the developing world tend to find a positive association between decentralization and territorial disparities, while the evidence from studies covering countries in the developed world is much more mixed.

\section{The link between decentralization and regional inequalities}

In this paper we revisit the link between fiscal and political decentralization and within country regional disparities, using a set of 26 countries. We pay special attention to how decentralization processes may operate differently in the developed and developing world, as, as stated in our hypothesis, we expect the implications of decentralization for regional disparities to differ according to the level of wealth and economic development of individual countries. As far as we are aware, no study has to date empirically investigated this possibility.

\subsection{Model}

In order to measure our dependent variable, the level and evolution of regional inequalities within each country, we resort to the population-weighted coefficient of variation. This measure of dispersion, which is widely used in the literature on regional 
disparities (e.g. Williamson, 1965; Petrakos, Rodríguez-Pose and Rovolis, 2005; Ezcurra and Pascual, 2008), adopts the following form:

$$
c_{c t}=\frac{\sqrt{\sum_{i=1}^{n_{c}} p_{i t}\left(y_{i t}-\mu_{c t}\right)^{2}}}{\mu_{c t}}
$$

where $y_{i t}$ and $p_{i t}$ denote the GDP per capita and population share of region $i$ in country $c$ during year $t$. In turn, $\mu_{c t}=\sum_{i=1}^{n_{c}} p_{i t} y_{i t}$. The advantage of this inequality measure vis-àvis other potential alternative measures of inequality is that it is independent of scale and population size, and satisfies the Pigou-Dalton transfer principle (Cowell, 1995). Likewise, $c$ takes into account the differences in population size across the various territorial units considered. This aspect has traditionally been overlooked by the literature on economic convergence that has flourished since the contributions of Barro and Sala-i-Martin $(1991,1992)$, despite the fact that, as noted by Petrakos, RodríguezPose and Rovolis (2005), omitting population size may greatly distort our perceptions of spatial inequality.

Measuring our key independent variable, the degree of fiscal decentralization of a country, is much more controversial for two reasons. First, the devolution of fiscal power from central to regional and local governments is a complex and multidimensional process (Martínez-Vázquez and McNab, 2003; Schneider, 2003). Second, no single indicator is able to adequately capture the real level of fiscal decentralization of a country (Ebel and Yilmaz, 2002). The indicator we use as a proxy for the level of fiscal decentralization of the countries considered is the subnational share in total government expenditure, which has been widely employed by the literature (e.g. Oates, 1985, 1993; Davoodi and Zou, 1998). This indicator has, however, 
come under strong criticism for failing to identify the degree of expenditure autonomy of subnational governments, for failing to differentiate between tax and non-tax revenue sources, and for its inability to capture the proportion of intergovernmental transfers that are discretionary or conditional (Ebel and Yilmaz, 2002; Rodden, 2004; Stegarescu, 2005). For large cross-country comparisons, as Rodríguez-Pose and Gill (2004) acknowledge, there is nevertheless a lack of reliable alternatives, making the subnational share in total government expenditure probably the best available quantitative indicator. With the exception of Gil, Pascual, and Rapún (2004), all existing cross-country analyses on the relationship between fiscal decentralization and regional disparities employ this measure, which facilitates the comparison of our results with those obtained previously in other studies.

Another handicap linked to the use of this proxy of fiscal decentralization is the scarcity of homogeneous and reliable cross-country data. This limits considerably the number of countries that can be included in this type of analysis. Our sample covers a total of 26 countries for which complete sets of data on regional GDP per capita and subnational share in total government expenditure are available (Table 1). This is however a larger sample than those employed by earlier works on the topic ${ }^{3}$.

In order to try to overcome some of the problems of using the subnational share in total government expenditure as a proxy of fiscal decentralization and to provide a more comprehensive picture of the actual powers of subnational governments, we introduce an indicator of political decentralization. Political decentralization has to do with the power of subnational governments to undertake the political functions of governance

\footnotetext{
${ }^{3}$ See the Appendix for a full description on the sources of the data used in the paper.
} 
(Schneider, 2003). However, measuring political decentralization is even more controversial than measuring fiscal decentralization, with virtually every researcher who has wandered into this field producing his or her own personal index of political decentralization ${ }^{4}$. In addition, political decentralization indices tend to cover a relatively small sample of developed countries, often disregard the significant changes in state structure in the developing world, and tend to be constrained to specific points in time. We use Schneider's (2003) 1996 political decentralization index, as it is the only one that covers all of the countries included in our sample, but which has the drawback of only referring to one year during our period of analysis. We also note that, while Schneider's index is broadly in line with other political decentralization indices (see Schakel, 2008), most of the countries included in the analysis register significant differences between their degree of political and fiscal decentralization, reflecting internal legal, political, and de facto discrepancies between the availability of funds for subnational governments and the power of these governments to make significant policy choices with them.

Taking into account the above discussion, our model adopts the following form:

$$
I_{c t}=\alpha+\beta F D_{c t}+\gamma P D_{c}+\varphi \mathbf{X}_{c t}+\varepsilon_{c t}
$$

where $I$ is our measure of regional inequality, $F D$ is the indicator of fiscal decentralization, $P D$ is Schneider's indicator of political decentralization, $\mathbf{X}$ denotes a set of indicators that control for additional factors that are assumed to have an influence on regional disparities, and $\varepsilon$ is the corresponding disturbance term.

\footnotetext{
${ }^{4}$ Please refer to the 2008 special issue of Federal and Regional Studies on "Regional Authority in 42 Countries, 1950-2006: A Measure and Five Hypotheses" by Hooghe, Marks, and Schakel in order to have a comprehensive view of the difficulties involved in creating an index of political decentralization and about the contrasts among individual indices.
} 
Our control variables in vector $\mathbf{X}$ include the wealth of the country and its size, the level of trade openness, whether a country has undergone transition from a socialist to a capitalist system, and the redistributive capacity of the state. The wealth of a country is proxied by GDP per capita. Since the pioneer work of Williamson (1965), the empirical literature on spatial inequality has emphasized the relevance of the level of economic development in explaining regional disparities (e.g. Amos, 1988; Terrasi, 1999; Petrakos, Rodríguez-Pose and Rovolis, 2005). From a theoretical perspective, it is difficult to determine beforehand the final effect of this variable on spatial inequality. While some factors such as the existence of diseconomies of agglomeration prevailing after some level of concentration, core-periphery spread effects, technological diffusion processes, or transport infrastructures that affect the locational choice of private capital, suggest that, beyond a certain threshold level, the advances in the economic development process may contribute to the spatial dispersion of economic activity (Petrakos and Brada, 1989; Thisse, 2000), new economic geography models have tended to highlight that economic growth is often associated with an uneven spatial development (e.g. Krugman, 1998; Fujita and Thisse, 2002).

Spatial inequality may also be related to country size (Williamson, 1965). Country size may hide greater heterogeneity and thus the possibility for subnational governments to undertake widely different policies than in smaller, more homogenous and compact countries. We use the population of a country as our measure of country size.

The rise in trade over recent decades has also attracted attention as a potential contributor to changes in inequality (e.g. Milanovic, 2002; Dollar and Kraay, 2004; 
Rodríguez-Pose and Gill, 2006). The impact of trade on inequalities is, however, not well understood yet. On the one hand, Heckscher-Ohlin type analyses indicate that trade contributes to reduce existing disparities, in the cases when capital investment is attracted by those regions with the lowest cost base and labour shifts to the highest salary zones. On the other, it should not be overlooked that, according to this theory, the owners of abundant factors will benefit from trade, while owners of scarce resources will experience falling returns, at least in the medium term. Likewise, the models of the new economic geography provide different outcomes in relation to the link between trade and spatial inequality, depending on the theoretical assumptions employed in each case (e.g. Krugman and Livas Elizondo, 1996; Puga and Venables, 1999; Paluzie, 2001). In view of these considerations, we control our estimations for the possible impact on regional disparities of the degree of international trade openness of the different countries, measured as the ratio between total trade (exports and imports) and GDP.

Transition from real socialism to capitalism is also bound to have affected the location of economic activities and thus territorial disparities. As is well-known, throughout the 1990s, a number of countries around the world - and especially in central and eastern Europe (CEE) - underwent profound changes of a political and economic nature as a consequence of the processes of restructuring, privatization, and liberalization that ensued the fall of communism. Various studies have identified an important increase in the level of spatial inequality within the CEE countries during the transition period (Petrakos, 2001; Ezcurra and Pascual, 2007) and the changes seem to have mainly benefited capital cities and major urban agglomerations (Bachtler, Downes and Gorzelak, 1999; Petrakos, 2001). In contrast, most areas specialized in agriculture and 
manufacturing suffered the negative effects of transition. We thus include a dummy variable for the four transition countries of our sample: Bulgaria, Hungary, Poland, and Romania.

Finally, as indicated in the theoretical section, the redistributive capacity of the state is likely to affect the level and evolution of territorial disparities within any given country. Any observed link between fiscal decentralization and regional disparities may be spurious if existing differences in the capacity of the state to redistribute financial resources across regions are ignored (Gil, Pascual and Rapún, 2004). Hence we control for the size of the public sector, measured as the share of total public expenditure in national GDP, as a proxy for the redistributive capacity of the countries in the sample. We expect the relationship between public sector expenditure and regional inequalities to be negative.

\subsection{Data and method}

Our dataset is an unbalanced panel covering 26 countries. The period of analysis goes from 1990 until 2005 and, although data availability is not the same for all countries included in the sample, the average number of observations for each country is 14.6, from a possible maximum of 16 . No country has fewer than 11 time observations (Table 1). 
A potentially serious problem when analysing the relationship between subnational disparities and fiscal decentralization is the possible existence of endogeneity: decentralization may affect the evolution of territorial inequalities and, in turn, be affected by them. As is known, the use of endogenous regressors implies that the explanatory variables are contemporaneously correlated with the disturbance term, affecting the consistency of the ordinary least squares estimator (OLS) (Greene, 2003). Bearing this in mind, we estimate model (2) using the instrumental variables method (IV), with lagged values of the measure of fiscal decentralization as instruments. In addition, all the estimates carried out are based on a robust variance matrix estimator which is valid in the presence of heteroskedasticity or serial correlation (Wooldridge, 2002). The use of country-specific effects was also considered. However, the various Ftests performed indicate that in all cases the country-specific effects are not jointly significant, thus justifying the chosen specification. In addition, the absence of countryspecific effects has the advantage of allowing us to introduce time-invariant variables in the list of regressors (and notably Schneider's index of political decentralization). Likewise, the inclusion of time-specific effects common to all countries does not improve the goodness of fit of model (2) ${ }^{5}$.

Finally, as the aim of the paper is analysing the changes in the spatial distribution of GDP per capita, rather than permanent cross-country differences in the level of regional inequality, we normalize the values of the inequality measure employed as dependent variable in model (2) by the average inequality registered during the study period in the country in question. This normalization, which is also applied to the explanatory variables, has the important advantage of avoiding the possible sensitivity of the results

\footnotetext{
${ }^{5}$ The results obtained when model (2) is estimated with country and time-specific effects are available from the authors upon request.
} 
of the analysis to the level of territorial disaggregation used to compute the level of regional inequality within each country.

\subsection{Empirical results.}

The information provided by Table 1 shows that the degree of spatial inequality and fiscal decentralization varies considerably across the sample countries. By and large, countries with a level of regional disparities above the mean register, on average, a level of fiscal decentralization below the mean and vice versa, which raises the possible issue of the existence of an inverse relationship between these two variables. In order to confirm this finding, we calculate the Spearman's rank correlation coefficient between the average values of the population-weighted coefficient of variation and the subnational share in total government expenditure, obtaining a value of -0.450 ( $\mathrm{p}$-value $=0.021)$. This result is in line with the empirical evidence provided previously by Shankar and Shah (2003) and Gil, Pascual and Rapún (2004) for different country samples. However, this preliminary conclusion should be met with caution, as the changes registered by both variables over the study period are not explicitly taken into account and the level of spatial inequality within the countries in our sample does not depend exclusively on their degree of fiscal decentralization, but on a raft of different factors.

In order to asses whether this relationship holds, we run model (2). The results obtained when model (2) is estimated show that a substantial proportion of the variation in spatial inequality in the countries considered is explained, with adjusted R-squared results ranging between 0.5 and 0.73 in different regressions (Table 2). 
The coefficients for the two different decentralization variables indicate the presence of a complex and wealth-sensitive relationship between decentralization and regional inequalities. Regarding fiscal decentralization, the first two columns of Table 2 denote that the coefficient of our measure of fiscal decentralization is not statistically significant, suggesting the absence of a link between the devolution of fiscal power from central to subnational governments and the evolution of regional disparities. However, as was argued in the theoretical section, the possible impact of fiscal decentralization may be contingent on the level of development of a country, with poorer countries more likely to witness an increase in regional disparities linked to fiscal decentralization. This hypothesis is corroborated by the results of the analysis. Using the World Bank classification as reference, model (2) is estimated separately for two subsamples of countries: a) the subsample of high income countries and b) the subsample of medium and low income countries (see Appendix 1 for further details on the classification employed).

The coefficients for our fiscal decentralization indicator in the last four columns of Table 2 reveal that the effect of fiscal decentralization on regional disparities differs clearly between developed and developing countries. As expected, in our low income country subsample the coefficient of the measure of fiscal decentralization is positive and statistically significant, pointing out that in these countries the processes of devolution of fiscal power from central to subnational governments contribute to greater regional inequality. This confirms the spatially regressive effects of fiscal 
decentralization indentified by Prud'homme (1995), Dillinger (2002) or Rodríguez-Pose and Gill $(2004,2005)$. In contrast, in our high income subsample the coefficient of the subnational share in total government expenditure is negative and statistically significant, meaning that beyond a certain wealth threshold, the negative effects of fiscal decentralization no only tend to disappear, but also that under certain circumstances a greater transfer of resources to subnational tiers of government may - in accordance with the empirical evidence provided by Gil, Pascual and Rapún (2004) and Ezcurra and Pascual (2008) for a sample of OECD and EU countries respectively - contribute to greater economic convergence.

Political decentralization is also disconnected from the evolution of regional disparities across the countries analysed. Whether regions have a greater political powers does not seem to make a difference for the evolution of economic disparities both in the whole sample and in the sub-sample of high income countries (Table 2). In contrast, in low income countries, the level of political decentralization appears to contribute to a reduction of the degree of spatial dispersion of the regional distribution of GDP per capita. The transfer of powers to subnational tiers of government in these countries may thus, after all, contribute to a perhaps greater dynamization of the local economic fabric and to mobilizing resources in areas that have possibly been operating well below their development potential. However, the inclusion of the political decentralization variable in Regression 6 (Table 2) does not affect the strength of the fiscal decentralization coefficient, which remains significantly stronger than that of political decentralization. This implies that the potentially positive effects of political decentralization for the evolution of regional inequality in parts of the developing world are more than cancelled out by the negative impact of the transfer of resources to implement 
autonomous policies to governments that often lack the adequate capacity or have to function difficult economic, social, and institutional conditions.

The inclusion of the remaining variables in model (2) does not affect the decentralization coefficients - confirming their robustness and showing that the effects of fiscal and political decentralization on spatial inequality discussed above are not spurious correlations resulting from the omission of relevant variables - and, by and large, tend to have the expected sign (Table 2). Of particular relevance given our starting hypotheses is the coefficient of public sector size. In the theoretical section we argued that in countries where the central government has a significant redistributive capacity the potentially negative effects of decentralization on regional disparities may be counterbalanced by the capacity of the central or federal state to channel resources and technical or political support to poorer subnational governments. In contrast, a lack of redistributive capacity would negatively affect the economic growth prospects of a poorer region when the resources of the local government are increasingly dependent on the local tax base or on their political bargaining capacity. The coefficients in Table 2 for public sector size confirm this. There is a strong and highly significant negative relationship between the size of the public sector - our proxy for the redistributive capacity - of a country and regional disparities. This relationship is particularly strong in the developing world. However, the coefficient is not significant for the developed country sub-sample, indicating the potential existence of a threshold of public intervention on the evolution of regional disparities.

Of the remaining variables included in model (2), Table 2 reveals that GDP per capita is in all cases positively correlated with regional disparities. Once we control for fiscal and 
political decentralization, public sector size, population, trade openness, and whether a country has undergone transition, country-wide advances in economic performance seem to be associated with greater spatial inequality. This suggests that the more dynamic regions over the study period were those initially more developed, underlining the spatially selective nature of the process of economic growth and the relevance in this context of agglomeration economies and increasing returns. Trade openness is, in contrast, not statistically significant in any of the samples considered, which is in line with the empirical evidence provided by Rodríguez-Pose and Gill (2006) for different countries. Note that this result does not mean that trade does not have spatial consequences: increasing trade will give rise to winning and losing regions. However, our finding suggest that on average the group of losing (winning) regions is not formed only by poor (rich) regions.

The results also indicate that population size - once other factors are controlled for - is negatively correlated with regional disparities. Nevertheless, this should be met with caution, as the relationship is not statistically significant for the high income countries. Finally, the dummy variable for the CEE countries is positive and statistically significant in all cases, confirming that the transition countries registered on average greater regional disparities than the rest during the period of analysis, once other factors are controlled for.

The results presented above may be affected by the choices subnational governments make about policies. Greater investment by regional governments in developing countries in economic affairs or other capital investments may result in greater territorial polarisation, as the more dynamic economic sectors are more concentrated in 
the main cities in these countries than in the developed world. A greater appetite for expenditure in health, in social protection, or other types of welfare or current expenditure could, in contrast, limit the expansion of territorial inequalities. Given the generally more equal distribution of economic activity in developed countries, differences in policy choices by subnational governments may have a more nuanced effect - if at all - on regional inequalities.

In order to demonstrate whether this is the case, we calculate the subnational share in total government expenditure on economic affairs, health, education, and social protection. As there are substantial differences among countries in their degree of devolution of fiscal power from central to regional and local governments, the different ratios of expenditure are weighted by the level of decentralization of total expenditure in each country.

Table 3 shows the results obtained when model (2) is estimated replacing the indicator of fiscal decentralization employed so far with the four measures defined above ${ }^{6}$. As expected, across the developed world variations in expenditure choices tend to be completely dissociated from the evolution of regional disparities. The only exception is that a subnational government preference for health expenditure in high income countries is associated with a reduction in regional disparities. In contrast, in the low

${ }^{6}$ Because of lack of full datasets on specific types of subnational expenditure, Brazil, Mexico, South Africa, and the United Kingdom had to be excluded from certain regressions in this part of the analysis, depending on the specific type of expenditure considered. 
and medium income countries included in the sample the differences in policy preferences among subnational governments have important implications for regional disparities. In these countries, preferences for subnational public expenditure on economic affairs, education, and, contrary to expectations, social protection have a statistically significant impact on spatial inequality. The positive signs of the corresponding coefficients show that the decentralization of these expenditures is associated with increasing disparities (Table 3). Preferences for subnational expenditure in health are, on the contrary, associated with a reduction of regional disparities, not only in the subsample of developing countries, but in the whole sample as well. The decentralization of health expenditure thus contributes to reduce the degree of spatial dispersion of GDP per capita, regardless of the level of economic development of the countries under consideration.

When weighing up the results obtained so far, it is worth gauging to what extent they depend on the specific measure we use to quantify the relevance of spatial inequality within the sample countries. Resorting to different inequality measures may actually yield different orderings of the distributions analysed, as each index has a different way of aggregating the information contained in the distribution (Sen, 1973).

For this reason, and in order to supplement the information provided by the coefficient of variation, we calculate the population-weighted standard deviation of the logarithm of regional per capita GDP:

$$
v_{c t}=\sqrt{\sum_{i=1}^{n_{c}} p_{i t}\left(\log y_{i t}-\tilde{\mu}_{c t}\right)^{2}}
$$


where $\tilde{\mu}_{t}=\sum_{i=1}^{n_{c}} p_{i t} \log y_{i t}$. This is a measure of dispersion that in its non-weighted version has been widely used in the convergence literature to capture the concept of sigma convergence (Barro and Sala-i-Martin, 1995). In addition, we also resort the two indices proposed by Theil (1967) within the information theory context:

$$
T(0)_{c t}=\sum_{i=1}^{n_{c}} p_{i t} \log \left(\frac{\mu_{c t}}{y_{i t}}\right)
$$

and

$$
T(1)_{c t}=\sum_{i=1}^{n_{c}} p_{i t}\left(\frac{y_{i t}}{\mu_{c t}}\right) \log \left(\frac{y_{i t}}{\mu_{c t}}\right)
$$

Both measures have been widely popular in the literature on personal income distribution and have been also used by numerous authors in order to analyse spatial disparities (e.g. Terrasi, 1999; Azzoni, 2001). As is the case with the coefficient of variation, all the indices selected are independent of scale and population size and, except for the standard deviation of the logarithm, they all fulfil the Pigou-Dalton transfer principle for the whole definition domain of income (Cowell, 1995).

Table 4 summarizes the results obtained when model (2) is estimated again using as dependent variable $v, T(0)$ and $T(1)$ in turn, instead of the coefficient of variation. As can be observed, our previous findings still hold, confirming the robustness of the results discussed above. This means that the detected effects of fiscal decentralization on spatial inequality do not depend on the indicator used to quantify the degree of 
dispersion in the regional distribution of per capita GDP within the different countries included in our study.

\section{Conclusions}

This paper has analysed the association between decentralization and regional inequalities across countries in the developed and the developing worlds. Although it is generally assumed that the transfer of powers and resources to subnational tiers of government may be detrimental for national economic cohesion, the results of our paper point that, across our sample of 26 countries, fiscal and political decentralization are completely disconnected from the evolution of regional disparities. This means that the institutional capacity, fiscal, and political constraints that the administrations of poorer regions may face with respect to that of wealthier, larger, or more powerful regions and states when greater autonomy is granted are likely to be offset by the greater capacity of governments in poorer areas to mobilise unexploited economic potential and to better tailor policies to the needs of local citizens, especially in areas that may have been ignored or considered a low priority for national policy intervention. The presence of a large national government with significant fiscal redistributive powers is another clear factor in reining the potentially negative effects of decentralization for peripheral areas.

However, the association between decentralization and the evolution of regional inequalities varies significantly according to the level of development of the country. Our results highlight that in the developed world political decentralization does not affect the evolution of regional disparities, while fiscal decentralization may contribute to reducing them. In contrast, fiscal decentralization has in the past triggered a 
significant rise in regional inequalities in the low income countries in our sample. This rise in inequalities cannot be compensated by the positive effects of political decentralization on regional disparities in these countries. As in most of these countries the redistributive capacity of the state is significantly weaker than in richer states, the potential for decentralization to have a detrimental effect on regional disparities rises significantly.

Different policy choices by subnational governments in our developed world subsample tend not to matter for the evolution of regional disparities. Whether subnational governments choose to invest in economic affairs, education, or social protection does not affect territorial inequality. The only exception is expenditure in health, which is connected to a reduction in disparities. In the developing world, greater capital investment in areas such as economic affairs or education tends to favour the development of core areas to the detriment of the periphery. Health expenditure, in contrast, favours economic convergence, but investment in social protection - contrary to expectations - is also associated with an increase in regional inequality.

The results of the paper highlight that the question of whether decentralization matters for territorial disparities may not be the most pertinent, but rather under which circumstances is decentralization likely to enhance or reduce regional inequality. The relationship between decentralization and the evolution of disparities at subnational level seems strongly affected by the level of wealth of a country, the dimension of its existing disparities, and the presence of solid fiscal redistribution systems. Hence, while high income countries, with limited internal disparities, a strong welfare state, and territorially progressive fiscal systems can expect that further decentralization will not 
harm their territorial cohesion (and, if anything, may increase it), low and medium income countries may have to tread more carefully as the potential positive effects of political decentralization on cohesion will be easily counterbalanced by the unequal capacity of regions in the core and in the periphery of these countries to make the most of decentralized resources, especially in the absence of well-established territorially progressive fiscal systems.

\section{References}

Amos, O.M. (1988): Unbalanced regional growth and regional income inequality in the latter stages of development, Regional Science and Urban Economics, 18: 549566.

Aspinall, E. and Berger, M.T. (2001): The break-up of Indonesia? Nationalisms after decolonisation and the limits of the nation-state in post-cold war Southeast Asia, Third World Quarterly, 22: 1003-1024.

Azzoni, C. R. (2001): Economic growth and income inequality in Brazil, Annals of Regional Science, 31: 133-152.

Bachtler, J., Downes, R. and Gorzelak, G. (2000): Transition, Cohesion and Regional Policy in Central and Eastern Europe. Aldershot: Ashgate Publishers.

Bagchi, A. (2003): Rethinking Federalism: Changing Power Relations Between the Center and the States, Publius: The Journal of Federalism, 33: 21-42.

Bardhan, P. (2002): Decentralization of governance and development, Journal of Economic Perspectives, 16: 185-205. 
Barro, R. and Sala-i-Martin, X. (1991): Convergence across states and regions, Brooking Papers on Economic Activity, 1: 107-182.

Barro, R. and Sala-i-Martin, X. (1992): Convergence, Journal of Political Economy, 100: $407-443$

Barro, R. and Sala-i-Martin, X. (1995): Economic Growth. New York: McGraw Hill.

Beramendi, P. (2007): Inequality and the territorial fragmentation of solidarity, International Organization, 61: 783-820.

Besley, T. and Ghatak, M. (2003): Incentives, choice, and accountability in the provision of public services, Oxford Review of Economic Policy, 19: 235-249.

Bonet, J. (2006): Fiscal decentralization and regional income disparities: Evidence from the Colombian experience, Annals of Regional Science, 40: 661-676.

Burki, S.J., Perry, G.E. and Dillinger, W.R. (1999): Beyond the Center: Decentralizing the State. Washington D.C.: World Bank.

Calamai, L. (2009): The link between devolution and regional disparities: evidence from the Italian regions, Environment and Planning $A$ advance online publication, doi:10.1068/a40282

Chen, J. and Fleischer, B.M. (1996) Regional income inequality and economic growth in China, Journal of Comparative Economics, 22: 141-164.

Cheshire, P.C. and Gordon, I.R. (1998): Territorial Competition: Some Lessons for Policy, Annuals of Regional Science, 32: 321-346.

Coutinho, M. (1996): The Brazilian fiscal system in the 1990s: Equity and efficiency under inflationary condition. University of London, Institute of Latin American Studies, Research Papers 41.

Cowell, F. (1995): Measuring Inequality, Second Edition, LSE Handbooks in Economics. London: Prentice Hall. 
Dabla-Norris, E (2006): The challenge of fiscal decentralization in transition countries, Comparative Economic Studies, 48: 100-131.

Davoodi, H. and Zou, H. (1998): Fiscal decentralization and economic growth: a cross country study, Journal of Urban Economics, 43: 244-257.

Dayal-Gulati, A. and Husain, A.M. (2002) Centripetal forces in china's economic takeoff. IMF Staff Papers, 49: 364-394.

de Winter, L. and Türsan, L., eds., (1998): Regionalist Parties in Western Europe. London: Routledge.

Dillinger, W. (2002): Brazil. Issues on fiscal federalism, Brazil Country Management Unit Report 22523-BR. Washington: World Bank.

Dillinger, W. and Webb, S.B. (1999): Fiscal management in federal democracies: Argentina and Brazil. World Bank Policy Research Working Paper 2121.

Dollar, D. and Kraay, A. (2004): Trade, growth and poverty, Economic Journal, 114: $22-49$.

Donahue, J. D. (1997) Disunited States. New York: HarperCollins Publishers.

Ebel, R.D. and Yilmaz, S. (2002): On the measurement and impact of fiscal decentralization, World Bank Policy Research Working Paper 2809.

Ezcurra, R. and Pascual, P. (2007): Spatial disparities in productivity in Central and Eastern Europe, Eastern European Economics, 45: 5-32.

Ezcurra, R. and Pascual, P. (2008): Fiscal decentralization and regional disparities: Evidence from several European Union countries, Environment and Planning A, 40: $1185-1201$.

Fujita M. and Thisse J.F. (2002): Economics of Agglomeration. Cambridge: Cambridge University Press. 
Gil, C., Pascual, P. and Rapún, M. (2004): Regional economic disparities and decentralization, Urban Studies, 41: 71-94.

Greene, W.H. (2003): Econometric Analysis, Third Edition. Englewood Cliffs, NJ: Prenctice Hall.

Hechter, M. (1992): The dynamics of secession, Acta Sociologica, 35: 267-283.

Hill, H. (2008): Globalization, inequality, and local-level dynamics: Indonesia and the Philippines, Asian Economic Policy Review, 3: 42-61.

Hooghe, L., Marks, G. and Schakel, A.H. (2008): Operationalizing Regional Authority: A Coding Scheme for 42 Countries, 1950-2006, Regional and Federal Studies, 18 : 123-142.

Horowitz, D.L. (1985): Ethnic Groups in Conflict. Berkeley: University of California Press.

Kanbur, K. and Zhang, X. (2005): Fifty years of regional inequality in China: a journey through central planning, reform, and openness, Review of Development Economics, 9: 87-106.

Keating, M. (1998): The new regionalism in Western Europe: territorial restructuring and political change. Northampton: Edward Elgar.

Krugman, P. (1998): What's new about the new economic geography?, Oxford Review of Economic Policy,14: 7-17.

Krugman, P. and Livas Elizondo, R. (1996): Trade policy and the third world metropolis, Journal of Development Economics, 49: 137-150.

Lee, J. (1995): Regional income inequality variations in China, Journal of Economic Development, 20: 99-118.

Ma, J. (1996): Intergovernmental Relations and Economic Management in China. New York: St. Martin's Press. 
Marks, G., Hooghe, L. and Schakel, A.H. (2008): Measuring Regional Authority, Regional and Federal Studies, 18: 111-121.

Martínez-Vázquez, J. and McNab, R. (2003): Fiscal decentralization and economic growth, World Development, 31: 1597-1616.

McKinnon, R. (1997): Market-preserving fiscal federalism in the American Monetary Union. In Blejer, M. and Ter-Minassian, T., eds., Macroeconomic Dimensions of Public Finance: Essays in Honour of Vito Tanzi: 73-93. London: Routledge.

Milanovic, B. (2002): Can we discern the effect on globalization on income distribution? Evidence from household budget surveys, World Bank Policy Research Working Paper 2876.

Moreno, L. (2001): The Federalization of Spain, The Cass series in regional and federal studies 5. London, Portland, OR: F. Cass.

Morgan, K. (2002): The English question: regional perspectives on a fractured nation, Regional Studies, 36: 797-810.

Ndegwa, N. (2002): Decentralization in Africa: A Stocktaking Survey. Africa Region Working Paper Series, No. 40. World Bank, Washington D.C.

Oates, W E (1972): Fiscal federalism. New York: Harcourt Brace Jovanovich.

Oates, W.E. (1985): Searching for Leviathan: An empirical analysis, American Economic Review, 75: 748-757.

Oates, W.E. (1993): Fiscal decentralization and economic development, National Tax Journal, XLVI: 237-243.

Oates, W E (1996): Estimating the demand for public goods: The collective choice and contingent valuation approaches. In Bjornstad, D and Kahn, J, eds., The Contingent Valuation of Environmental Resources, pp. 211-30. Cheltenham: Edward Elgar. 
Oates, W.E. (1999): An essay on fiscal federalism, Journal of Economic Literature, 37: $1120-1149$

Paluzie, E. (2001): Trade policy and regional inequalities, Papers in Regional Science, 80: 67-86.

Petrakos, G. (2001): Patterns of regional inequality in transition economies, European Planning Studies, 9: 359-383.

Petrakos, B. and Branda, J. (1989): Metropolitan concentration in developing countries, Kyklos, 42: 556-578.

Petrakos, G., Rodríguez-Pose, A. and Rovolis, A. (2005): Growth, integration and regional inequality in Europe, Environment and Planning A, 37: 1837-1855.

Pike, A. and Tomaney, J. (2009) The state and uneven development, Cambridge Journal of Regions, Economy and Society 2009, 2: 13-34.

Prud'homme, R. (1995): On the dangers of decentralization, World Bank Policy Research Working Paper 1252.

Puga, D. and Venables, A.J. (1999): Agglomeration and economic development: Import substitution vs. trade liberalisation, Economic Journal, 109: 292-311.

Qian, Y. and Weingast, B. (1997): Federalism as a commitment to preserving market incentives, Journal of Economic Perspectives, 11: 83-92.

Qiao, B., Martínez-Vázquez, J. and Xu, Y. (2008): The tradeoff between growth and equity in decentralization policy: China's experience, Journal of Development Economics, 86: 112-128.

Rao, M.G. and Singh, N. (2007) The Political Economy of India's Federal System and its Reform, Publius The Journal of Federalism, 37: 26-44

Rodden, J. (2004): Comparative federalism and decentralization: On meaning and measurement, Comparative Politics, 36: 481-500. 
Rodríguez, V.E. (1997): Decentralization in Mexico: From Reforma Municipal to Solidaridad to Nuevo Federalismo. Boulder, Col: Westview Press.

Rodríguez-Pose, A. and Gill, N. (2004): Is there a global link between regional disparities and devolution?, Environment and Planning A, 36: 2097-2117.

Rodríguez-Pose, A. and Gill, N. (2005): On the "economic dividend" of devolution, Regional Studies, 39: 405-420.

Rodríguez-Pose, A. and Gill, N. (2006): How does trade affect regional disparities?, World Development, 34: 1201-1222.

Rodríguez-Pose, A. and Sandall, R. (2008): From identity to the economy: analysing the evolution of the decentralisation discourse, Environment and Planning $C$ : Government and Policy, 26: 54-72.

Schakel, A.H. (2008): Validation of the Regional Authority Index, Regional and Federal Studies, 18: 143-166.

Schneider, A. (2003): Decentralization: conceptualization and measurement, Studies in Comparative International Development, 38: 32-56.

Sen, A. (1973): On Economic Inequality . Oxford: Oxford University Press.

Silva, J.A. (2005): Devolution and regional disparities in the Philippines: is there a connection?, Environment and Planning C: Government and Policy, 23: 399-417.

Shankar, R. and Shah, A. (2003): Bridging the economic divide within countries: A scorecard on the performance of regional policies in reducing regional income disparities, World Development, 31: 1421-1441.

Sharma, S. D. (1999): Development and democracy in India. Boulder, Co: Lynne Rienner.

Stegarescu, D. (2005): Public sector decentralisation: Measurement concepts and recent international trends, Fiscal Studies, 26: 301-333. 
Terrasi, M. (1999): Convergence and divergence across Italian regions, Annals of Regional Science, 33: 491-510.

Theil, H. (1967): Economics and Information Theory. Amsterdam: North Holland.

Thisse, J.F. (2000): Agglomeration and regional imbalance: Why? And is it bad?, Papers of the European Investment Bank, 5: 47-67.

Tiebout, C.M. (1956): A pure theory of local expenditures. Journal of Political Economy, 64: 416-424.

Tsui, K.Y. (1993): Decomposition of China's Regional Inequalities, Journal of Comparative Economics, 17: 600-627.

Ward, P.M. and Rodríguez, V.E. (1999): New Federalism and State Government in Mexico: Bringing the States Back In, A.S.-Mexican Policy Report 9, University of Texas at Austin.

Warner, M.E. and Pratt, J.E. (2005): Spatial diversity in local government revenue effort under decentralization: a neural-network approach, Environment and Planning C: Government and Policy, 23: 657-677.

Wei, S.J. and Wu, Y. (2001): Globalization and Inequality: Evidence from Within China. NBER Working Paper, vol. 8611. National Bureau of Economic Research, Cambridge, MA.

Weingast, B. (1995): The economic role of political institutions: Market-preserving federalism and economic growth, Journal of Law, Economics and Organization, 11: $1-31$.

West, L.A. and Wong, C.P.W. (1995): Fiscal decentralization and growing regional disparities in rural China: Some evidence in the provision of rural services, Oxford Review of Economic Policy, 11: 70-84. 
Williamson, J. G. (1965): Regional inequality and the process of national development: A description of patterns, Economic Development and Cultural Change, 13: 3-45.

World Bank (2000) The World Development Report 1999/2000. Entering the 21st Century. Washington, D.C.: The World Bank and Oxford: Oxford University Press.

Wooldridge, J. M. (2002): Econometric Analysis of Cross Section and Panel Data. Cambridge: MIT Press. 


\section{Appendix}

List of countries:

High income countries: Australia, Austria, Belgium, Canada, Denmark, Finland, France, Germany, Hungary, Ireland, Italy, Netherlands, Norway, Portugal, Spain, Sweden, Switzerland, United Kingdom, United States.

Low income countries: Brazil, Bulgaria, Mexico, Poland, Romania, South Africa, Thailand.

These groups are based on the classification adopted by the World Bank according to the per capita income level of the different countries. See www.worldbank.org for further details. 
Tables

Table 1: Spatial inequality and fiscal decentralization in the sample countries.

\begin{tabular}{|c|c|c|c|c|c|}
\hline \multirow[b]{2}{*}{ Country } & \multirow[b]{2}{*}{ Period } & \multicolumn{2}{|c|}{ Spatial inequality } & \multicolumn{2}{|c|}{ Fiscal decentralization } \\
\hline & & Mean & Std. Dev. & Mean & Std. Dev. \\
\hline Australia & $1990-2005$ & 0.368 & 0.027 & 0.994 & 0.012 \\
\hline Austria & 1990-2004 & 0.859 & 0.011 & 1.081 & 0.014 \\
\hline Belgium & 1990-2004 & 1.295 & 0.008 & 1.129 & 0.020 \\
\hline Brazil & 1990-2004 & 1.674 & 0.021 & 1.126 & 0.060 \\
\hline Bulgaria & 1990-2004 & 0.645 & 0.040 & 0.582 & 0.039 \\
\hline Canada & $1990-2005$ & 0.537 & 0.024 & 1.566 & 0.020 \\
\hline Denmark & 1990-2004 & 0.519 & 0.009 & 1.319 & 0.014 \\
\hline Finland & 1990-2004 & 0.578 & 0.013 & 1.245 & 0.027 \\
\hline France & 1990-2004 & 0.967 & 0.006 & 0.779 & 0.013 \\
\hline Germany & 1994-2004 & 0.748 & 0.004 & 1.670 & 0.047 \\
\hline Hungary & $1990-2004$ & 1.193 & 0.071 & 0.745 & 0.020 \\
\hline Ireland & 1990-2004 & 0.552 & 0.023 & 0.705 & 0.024 \\
\hline Italy & 1990-2004 & 0.963 & 0.008 & 0.839 & 0.055 \\
\hline Mexico & 1993-2004 & 2.116 & 0.015 & 0.916 & 0.052 \\
\hline Netherlands & 1990-2004 & 0.454 & 0.012 & 0.966 & 0.021 \\
\hline Norway & 1990-2004 & 0.854 & 0.038 & 0.921 & 0.063 \\
\hline Poland & 1990-2004 & 0.715 & 0.041 & 1.318 & 0.186 \\
\hline Portugal & 1990-2004 & 1.043 & 0.020 & 0.382 & 0.015 \\
\hline Romania & 1990-2004 & 0.872 & 0.136 & 0.424 & 0.050 \\
\hline South Africa & $1995-2005$ & 1.832 & 0.026 & 1.031 & 0.008 \\
\hline Spain & 1990-2004 & 0.761 & 0.007 & 1.150 & 0.068 \\
\hline Sweden & 1990-2004 & 0.639 & 0.020 & 1.092 & 0.033 \\
\hline Switzerland & 1990-2004 & 0.565 & 0.010 & 1.771 & 0.032 \\
\hline Thailand & 1994-2005 & 3.930 & 0.049 & 0.183 & 0.021 \\
\hline United Kingdom & 1990-2004 & 0.841 & 0.014 & 0.602 & 0.020 \\
\hline United States & 1990-2005 & 0.480 & 0.009 & 1.462 & 0.032 \\
\hline
\end{tabular}

Notes: Spatial inequality is measured using the population-weighted coefficient of variation of regional GDP per capita. The indicator of fiscal decentralization is in turn the subnational share in total government expenditure. The average levels of fiscal decentralization of the various countries are normalized according to the sample mean. 
Table 2: The impact of fiscal decentralization on spatial inequality: regression analysis (IV method).

\begin{tabular}{|c|c|c|c|c|c|c|}
\hline Explanatory variables & (1) & (2) & (3) & (4) & $(5)$ & (6) \\
\hline \multirow[t]{2}{*}{ Constant } & $2.026 * * *$ & $2.016 * * *$ & 0.758 & 0.757 & $1.857 * *$ & $1.911 * *$ \\
\hline & $(0.567)$ & $(0.568)$ & $(0.824)$ & $(0.827)$ & $(0.528)$ & $(0.516)$ \\
\hline \multirow[t]{2}{*}{ Fiscal decentralization: total expenditure } & 0.286 & 0.287 & $-0.268 * *$ & $-0.265 * *$ & $0.512 * * *$ & $0.511 * * *$ \\
\hline & $(0.211)$ & $(0.212)$ & $(0.107)$ & $(0.109)$ & $(0.132)$ & $(0.130)$ \\
\hline \multirow[t]{2}{*}{ Political decentralization } & & 0.010 & & 0.008 & & $-0.095 * *$ \\
\hline & & $(0.025)$ & & $(0.020)$ & & $(0.031)$ \\
\hline \multirow[t]{2}{*}{ GDP per capita } & $0.921 * * *$ & $0.919 * * *$ & $0.705 * * *$ & $0.704 * * *$ & $1.319 * * *$ & $1.342 * * *$ \\
\hline & $(0.188)$ & $(0.187)$ & $(0.193)$ & $(0.194)$ & $(0.295)$ & $(0.280)$ \\
\hline \multirow[t]{2}{*}{ Population } & $-1.548 * *$ & $-1.544 * *$ & 0.043 & 0.041 & $-2.057 * * *$ & $-2.065 * * *$ \\
\hline & $(0.679)$ & $(0.681)$ & $(1.068)$ & $(1.070)$ & $(0.413)$ & $(0.396)$ \\
\hline \multirow[t]{2}{*}{ Trade openness } & -0.050 & -0.050 & -0.047 & -0.049 & 0.112 & 0.105 \\
\hline & $(0.092)$ & $(0.092)$ & $(0.112)$ & $(0.114)$ & $(0.140)$ & $(0.145)$ \\
\hline \multirow[t]{2}{*}{ Transition } & $0.042 * * *$ & $0.040 * * *$ & $0.038 * * *$ & $0.036 * * *$ & $0.074 * * *$ & $0.090 * * *$ \\
\hline & $(0.009)$ & $(0.009)$ & $(0.005)$ & $(0.008)$ & $(0.018)$ & $(0.017)$ \\
\hline \multirow[t]{2}{*}{ Public sector size } & $-0.634 * *$ & $-0.635 * *$ & -0.191 & -0.194 & $-0.765 * * *$ & $-0.767 * * *$ \\
\hline & $(0.231)$ & $(0.231)$ & $(0.169)$ & $(0.173)$ & $(0.064)$ & $(0.062)$ \\
\hline Adjusted R-squared & 0.520 & 0.519 & 0.501 & 0.500 & 0.730 & 0.731 \\
\hline Sample & All countries & All countries & High income & High income & Low income & Low income \\
\hline Number of countries & 26 & 26 & 19 & 19 & 7 & 7 \\
\hline Observations & 354 & 354 & 263 & 263 & 91 & 91 \\
\hline
\end{tabular}

Notes: The dependent variable is in all cases the population-weighted coefficient of variation of regional GDP per capita.

Robust standard errors in parentheses (see the main text for further details).

* significant at $10 \% ; * *$ significant at $5 \% ; * * *$ significant at $1 \%$. 
Table 3: Decentralization of different types of expenditure and spatial inequality: regression analysis (IV method).

\begin{tabular}{|c|c|c|c|c|c|c|}
\hline Explanatory variables & $(1)$ & (2) & (3) & (4) & $(5)$ & (6) \\
\hline \multirow[t]{2}{*}{ Constant } & $2.404 * *$ & 0.693 & $2.811 * * *$ & $2.259 * *$ & 0.754 & 1.771 \\
\hline & $(0.876)$ & $(0.787)$ & $(0.497)$ & $(0.891)$ & $(0.827)$ & $(1.756)$ \\
\hline \multirow[t]{2}{*}{ Decentral. of economic affairs expenditure } & 0.069 & -0.076 & $0.428 * *$ & & & \\
\hline & $(0.081)$ & $(0.062)$ & $(0.113)$ & & & \\
\hline \multirow[t]{2}{*}{ Decentral. of health expenditure } & & & & $-0.078 * *$ & $-0.066^{* *}$ & $-0.100 * * *$ \\
\hline & & & & $(0.029)$ & $(0.024)$ & $(0.017)$ \\
\hline Adjusted R-squared & 0.517 & 0.492 & 0.629 & 0.563 & 0.487 & 0.742 \\
\hline Sample & All countries & High income & Low income & All countries & High income & Low income \\
\hline Number of countries & 23 & 18 & 5 & 22 & 18 & 4 \\
\hline Observations & 305 & 249 & 56 & 303 & 249 & 54 \\
\hline Control variables & Yes & Yes & Yes & Yes & Yes & Yes \\
\hline
\end{tabular}

Notes: See Table 2

Table 3 (continuation).

\begin{tabular}{|c|c|c|c|c|c|c|}
\hline Explanatory variables & (7) & $(8)$ & $(9)$ & $(10)$ & $(11)$ & $(12)$ \\
\hline Constant & $\begin{array}{c}2.350 * * * \\
(0.807)\end{array}$ & $\begin{array}{c}0.776 \\
(0.846)\end{array}$ & $\begin{array}{c}4.297 * * * \\
(0.388)\end{array}$ & $\begin{array}{c}2.345 * * \\
(0.835)\end{array}$ & $\begin{array}{c}0.933 \\
(0.890)\end{array}$ & $\begin{array}{c}1.839 \\
(1.267)\end{array}$ \\
\hline Decentral. of education expenditure & $\begin{array}{l}0.151 * \\
(0.075)\end{array}$ & $\begin{array}{l}-0.103 \\
(0.072)\end{array}$ & $\begin{array}{c}0.250 * * * \\
(0.010)\end{array}$ & & & \\
\hline Decentral. of social protection expenditure & & & & $\begin{array}{c}0.123 \\
(0.083)\end{array}$ & $\begin{array}{c}-0.004 \\
(0.033)\end{array}$ & $\begin{array}{c}0.245 * * * \\
(0.041)\end{array}$ \\
\hline Adjusted R-squared & 0.596 & 0.475 & 0.799 & 0.520 & 0.465 & 0.717 \\
\hline Sample & All countries & High income & Low income & All countries & High income & Low income \\
\hline Number of countries & 22 & 18 & 4 & 23 & 18 & 5 \\
\hline Observations & 303 & 249 & 54 & 298 & 248 & 50 \\
\hline Control variables & Yes & Yes & Yes & Yes & Yes & Yes \\
\hline
\end{tabular}


Table 4: Sensitivity of the results to the measure of spatial inequality: regression analysis (IV method).

\begin{tabular}{|c|c|c|c|c|c|c|c|c|c|}
\hline \multirow{2}{*}{$\begin{array}{l}\text { Dependent variable } \\
\text { Sample }\end{array}$} & \multicolumn{3}{|c|}{$v$} & \multicolumn{3}{|c|}{$T(0)$} & \multicolumn{3}{|c|}{$T(1)$} \\
\hline & All & High income & Low income & All & High income & Low income & All & High income & Low income \\
\hline \multirow[t]{2}{*}{ Decen. of total expenditure } & 0.235 & $-0.259 * *$ & $0.423 * * *$ & 0.450 & $-0.525 * *$ & $0.821 * * *$ & 0.476 & $-0.453 *$ & $0.851 * * *$ \\
\hline & $(0.165)$ & $(0.116)$ & $(0.111)$ & $(0.337)$ & $(0.219)$ & $(0.211)$ & $(0.340)$ & $(0.234)$ & $(0.220)$ \\
\hline \multirow[t]{2}{*}{ Decen. of economic affairs expenditure } & 0.048 & -0.073 & $0.342 * *$ & 0.085 & -0.154 & $0.655 * *$ & 0.098 & -0.148 & $0.693 * *$ \\
\hline & $(0.065)$ & $(0.060)$ & $(0.095)$ & $(0.133)$ & $(0.124)$ & $(0.153)$ & $(0.137)$ & $(0.127)$ & $(0.159)$ \\
\hline \multirow[t]{2}{*}{ Decen. of health expenditure } & $-0.070 * * *$ & $-0.070 * *$ & $-0.077 * * *$ & $-0.164 * * *$ & $-0.131 * *$ & $-0.204 * *$ & $-0.166 * *$ & $-0.125 * *$ & $-0.215 * *$ \\
\hline & $(0.018)$ & $(0.024)$ & $(0.005)$ & $(0.057)$ & $(0.047)$ & $(0.040)$ & $(0.063)$ & $(0.048)$ & $(0.049)$ \\
\hline \multirow[t]{2}{*}{ Decen. of education expenditure } & 0.104 & -0.101 & $0.190 * * *$ & 0.239 & -0.173 & $0.419 * * *$ & 0.256 & -0.209 & $0.445 * * *$ \\
\hline & $(0.065)$ & $(0.077)$ & $(0.010)$ & $(0.140)$ & $(0.163)$ & $(0.043)$ & $(0.152)$ & $(0.141)$ & $(0.043)$ \\
\hline \multirow[t]{2}{*}{ Decen. of social protection expenditure } & 0.102 & -0.005 & $0.200 * * *$ & 0.192 & -0.018 & $0.374 * *$ & 0.194 & -0.004 & $0.390 * *$ \\
\hline & $(0.067)$ & $(0.032)$ & $(0.028)$ & $(0.141)$ & $(0.068)$ & $(0.083)$ & $(0.147)$ & $(0.060)$ & $(0.090)$ \\
\hline
\end{tabular}

Notes: All the regressions include the full set of control variables.

Robust standard errors in parentheses (see the main text for further details).

* significant at $10 \%$; ** significant at $5 \%$; *** significant at $1 \%$. 
Table A1: Data sources.

\begin{tabular}{|c|c|c|}
\hline Variable & Source & Comments \\
\hline Regional GDP per capita & $\begin{array}{l}\text { Cambridge Econometrics and } \\
\text { national statistics }\end{array}$ & Time varying (annual) \\
\hline $\begin{array}{l}\text { Fiscal decentralization } \\
\text { variables }\end{array}$ & $\begin{array}{l}\text { International Monetary Fund's } \\
\text { Government and Finance } \\
\text { Statistics }\end{array}$ & Time varying (annual) \\
\hline GDP per capita & $\begin{array}{l}\text { World Development Indicators } \\
\text { (World Bank) }\end{array}$ & Time varying (annual) \\
\hline Trade openness & $\begin{array}{l}\text { World Development Indicators } \\
\text { (World Bank) }\end{array}$ & Time varying (annual) \\
\hline Population & $\begin{array}{l}\text { World Development Indicators } \\
\text { (World Bank) }\end{array}$ & Time varying (annual) \\
\hline Transition & $\begin{array}{l}\text { World Development Indicators } \\
\text { (World Bank) }\end{array}$ & Time invariant (dummy) \\
\hline Public sector size & $\begin{array}{l}\text { World Development Indicators } \\
\text { (World Bank) }\end{array}$ & Time varying (annual) \\
\hline Political decentralization & Schneider (2003) & Time invariant (data for 1996) \\
\hline
\end{tabular}

Note: See the main text for further details on the definition of the different variables. 


\section{BERR}

\section{Spatial Economics Research Centre (SERC)}

London School of Economics

Houghton Street

London WC2A 2AE

Tel: 02078523565

Fax: 02079556848

Web: www.spatialeconomics.ac.uk

SERC is an independent research centre funded by the Economic and Social Research Council (ESRC), Department for Business, Enterprise and Regulatory Reform (BERR), the Department for Communities and Local Government (CLG) and the Welsh Assembly Government. 